ARAŞTIRMA / RESEARCH

\title{
Hemşirelik öğrencilerinde kendini sabotaj: psikolojik ihtiyaçlar ve öz- duyarlık üzerine etkisi
}

Self handicapping in nursing students: effects on psychological needs and self compassion

Adeviye Aydın1 (D), Nilgün Kahraman²

${ }^{1}$ Sinop Üniversitesi Sağllk Bilimleri Fakültesi Hemşirelik Bölümü, Sinop, Turkey

${ }^{2}$ Kastamonu Üniversitesi Fazıl Boyner Sağlık Bilimleri Fakültesi Hemşirelik Bölümü, Kastamonu, Turkey

\begin{abstract}
Cukurova Medical Journal 2020;45(4):1625-1633
Abstract

Purpose: Self-handicapping is an effective defense strategy that leads to poor performance in different situations such as individual behavior and education. It is aimed to examine the effects of self-handicapping on the psychological needs and self compassion level of nursing students.

Materials and Methods: This is a cross-sectional descriptive study was conducted with 482 types of nursing education students at two universities in Turkey. Introductory Information Form, Self-Handicapping Scale, Balanced Measure of Psychological Needs Satisfaction Scale and Self-Compassion Scale were used in the data collection,

Results: It was determined that the students' self compassion score was medium, the highest awareness and the lowest self-judgment score. Significant differences were found according to gender and age variable. A negative correlation was determined between the selfhandicapping score of the nursing students and the total self compassion score and the sub-dimensions of the psychological needs balance satisfaction scale. It was determined that self-handicapping score explained the total self compassion score by $26 \%$.

\section{Öz}

Amaç: Kendini sabotaj, bireyin davranıșında, eğitim gibi farklı durumlarda zayıf performansa yol açan bir savunma stratejisidir. Hemşirelik öğrencilerinin kendini sabotajin psikolojik ihtiyaçlar ve öz duyarllık düzeyine etkisinin incelenmesi amaçlanmıștır.

Gereç ve Yöntem: Tanımlayıcı bu çalışma kesitsel türde olup Türkiye'de iki üniversitede eğitim-öğretim gören 482 hemşirelik öğrencileriyle gerçekleştirilmiştir. Veri toplamada Tanıtıcı Bilgi Formu, Kendini Sabotaj Ölçeği, Psikolojik İhtiyaç Doyumunda Denge Ölçeği ve ÖzDuyarlık Ölçeği kullanılmıştır.

Bulgular: Öğrencilerin öz-duyarlık puanının orta düzeyde olduğu, en yüksek bilinçlilik en düşük öz yargılama puanının olduğu saptanmıştır. Cinsiyet ve yaş değişkenine göre anlamlı farklılıklara rastlanmıştır. Hemşirelik ögrencilerinin kendini sabotaj puanı ile öz-duyarlık toplam puanı ve psikolojik ihtiyaçlar denge doyumu ölçeğinin alt boyutları arasında negatif yönde bir ilișki belirlenmiștir. Kendini sabotaj puanı öz-duyarlılık toplam puanını \%26 açıkladığı belirlenmiștir.

Sonuç: Elde edilen bulgular kendini sabotaj puanı azaldıkça psikolojik ihtiyaçlar ve öz-duyarlılık puanlarının arttığını göstermektedir.
\end{abstract}

Conclusion: The findings obtained show that as the selfhandicapping score decreases, psychological needs and self compassion scores increase.

Keywords:. Self-handicapping, psychological needs, self compassion, nursing students
Anahtar kelimeler: Kendini sabotaj, psikolojik ihtiyaçlar, öz-duyarlık, hemşirelik öğrencileri 


\section{GİRİŞ}

Başarı yaşam boyu istenilen ve gerçekleştirilmesi beklenilen temel gereksinimlerden biridir. Üniversite yaşamı da çeşitli çabalar sonucu başarının yakalanarak mesleğe adım atmanın ilk basamağını oluşturmaktadır. Bu dönem boyunca birey başarısızlık deneyimi de yaşamakta ve çeşitli engellerle karşı karşıya kalmaktadır ${ }^{1}$. Birey karşılaştığ zorluklarla mücadele ederken farklı stratejiler kullanmaktadır. Birey bu engellerin üstesinden gelmede kullandığ stratejilerden biri de kendini sabotajdir.

Kendini sabotaj kavramını Berglas ve Jones (1978)'de bireyin performansını belirlemesinde başarısızlığ1 dışsallaştırması ve başarıyı ise içselleştirmesi olarak tanımlamıştır ${ }^{2}$. $\mathrm{Bu}$ kişiler yetenekleri ile performansları arasında engeller kullanır. Başkalarının kendileri hakkında olumlu bir bakış açısına sahip olması için kendini olduğundan farklı görünmeye zorlamaktadır ${ }^{3}$. Aslında kendini sabotajın en önemli yönü bireyin benliğini koruma isteğidir ${ }^{4}$. Dolayısıyla aslında kendini sabotaj farklı psikolojik kavramlarla iç içedir. Literatür incelemesinde kendini sabotajla, bilişsel çarpıtma, benlik saygısı, psikolojik iyi olma gibi değişkenlerle çalışıldığı belirlenmiştir. Kendini sabotajla psikolojik iyi olma arasında negatif bir ilişki bulunmakta olup ${ }^{1}$ bilişsel çarpitmaların fazla kullanılmasının ise kendini sabotaj eğiliminin artmasına yol açmaktadır ${ }^{5}$. Bir diğer çalışmada benlik sayg1sı yükseldikçe kendini sabotaj durumunun azaldığ1 görülmüştür ${ }^{6}$. Kişinin içsel yaşantısına yönelik farkındalı̆̆ının artması, özyeterliliğinin güçlendirilmesi ve kendini kabul etmesi sabotaj davranıșının önlenmesine yardımcı olacaktır ${ }^{7}$. Bu noktada sağlık profesyonelinin de kendine de duyarlı olması önemlidir.

Öz-duyarlık duyarlılık kavramıyla yakından ilişkili olup hemşirelik bakımı sağlayıcılarını da yakından ilgilendirmektedir. Öz duyarlılık kişinin karşısındaki kişilere gösterdiği anlayış, hoşgörü ve hassasiyeti kendisine de yansıtmasıdır ${ }^{8}$. Bakım ilişkisinde birebir hastaya duyulan empati ve sempati yeteneği belirli bir süre sonra tükenmeye ve kendine yabancılaşmaya neden olabilmektedir. Oysa kișinin kendi ruhsal durumuna sağlayacağı olumlu katkı bakımını da güçlendirecektir. Dolayısıyla bireyin kendisi için sıkıntı, keder, üzüntü ve acı oluşturan duygularına açık olması, yetersiz ve başarısız olduğu alanları kabullenmesi ve insan yaşamında doğal bir süreç olduğunu söylemesi onun öz duyarlılık kapasiteleriyle ilgilidir. Öz duyarlılığın incelendiği çalışmalarda hemşirelik öğrencilerinde öz duyarlılığın orta düzeyde olduğu belirlenmiştir ${ }^{9-11}$. Oysaki yüksek öz-duyarlığın psikolojik ihtiyaçları karşılama ${ }^{12}$ ve kendini sabotaj1 engelleme özelliğinin olabileceği görülmektedir ${ }^{13}$.

Psikolojik ihtiyaçlar bireyin bütüncül yapısı göz önüne alındığında fiziksel ve sosyal ihtiyaçlar kadar önemlidir. Psikolojik ihtiyaçlar kişinin saygınlık kazanmas1, kendini güvende hissetmesi, olumlu kişilerarası ilişkiler kurması, bir aile, grup meslek üyesine aidiyet hissetmesi, başarılı olması ve takdir edilmesi gibi durumlardir ${ }^{14}$. $\mathrm{Bu}$ ihtiyaçların karşılanmaması bireyde tatminsizlik, mutsuzluk, kayg1 ve sağlıksız bir ruhsal durum doğurabilmektedir. Hemşirelik öğrencilerinin psikolojik ihtiyaçlarını fark etmesi ve bunlardan memnun olma durumunu belirlemesi mesleki ve kişisel performansıyla oldukça ilişkilidir. Aynı zamanda öğrencilik durumunda karşılanmamıs psikolojik ihtiyaçların onun fiziksel ve sosyal iyilik durumunu da bozabileceğini düşündürmektedir.

Tüm bu nedenle hemşirelik öğrencilerinde psikolojik ihtiyaçların denge durumunun, öz duyarlılık seviyesinin araştırılması ve bu kavramlarla kendini sabotaj durumu arasındaki ilişkinin tanımlanması oldukça önem kazanmaktadır. Bu doğrultuda hemşirelik öğrencilerinin kendini sabotaj psikolojik ihtiyaçlar ve öz duyarlılık düzeyine etkisinin incelenmesi amaçlanmıştır. Bu çalışmadaki araştırma soruları şu şekildedir: Hemşirelik öğrencilerinin kendini sabotaj, psikolojik ihtiyaç denge doyumu, özduyarlık düzeyleri nedir? Hemşirelik öğrencilerinin kendini sabotaj, psikolojik ihtiyaç ve öz-duyarlıkları sosyo-demografik özelliklerine göre nasıl dağılım göstermektedir? Hemşirelik öğrencilerinin kendini sabotaj, psikolojik ihtiyaç ve öz duyarlılıkları puanları arasında ilişki var mıdır? Hemşirelik öğrencilerinin kendini sabotaj puanlarını etkileyen değişkenler nedir?

\section{GEREÇ VE YÖNTEM:}

Bu çalışma, tanımlayıcı kesitsel türde bir ilişki saptama çalışmasıdır. Araştırma evrenini Türkiye'de bulunan iki devlet üniversitesinde 2018-2019 eğitim öğretim y1lında öğrenimine devam etmekte olan hemşirelik bölümü öğrencileri oluşturmaktadır. Araştırmaya gönüllü olarak katılmayı kabul eden, amaçı örnekleme yöntemi ile seçilen ve veri toplama formlarını eksiksiz bir şekilde tamamlayan 482 öğrenci çalışmaya katılmıştır. Daha önce benzer bir 
çalışma olmadığından güç analizinde çalışma sonrası yapılması tercih edilmiştir. PASS 11 programında gerçekleştirilen analiz sonucunda Tip 1 hata alfa .005 'de 482 kişi ile gerçekleştirilen çalışmanın gücü $\% 100$ olduğu belirlenmiştir.

\section{Veri toplama araçları}

Araştırmada, "Tanıtıcı Bilgi Formu" "Kendini Sabotaj Ölçeği" "Psikolojik İhtiyaç Doyumunda Denge Ölçeğì" ve “Öz-Duyarlllık Ölçeği" kullanılmıştır.

\section{Tan1t1cı bilgi formu}

Öğrencilerin demografik bilgilerini içeren bu form yaş, cinsiyet, sınıf, anne baba eğitim düzeyi gibi sorulardan oluşmaktadır.

\section{Kendini Sabotaj Ölçeği (KSÖ)}

Jone ve Rhodewalt ${ }^{15}$ tarafindan geliştirilen ölçeğin Türkçe geçerlilik güvenirliğini Akın'16'gerçekleştirmiştir. Ölçek 25 maddeli 6'lı likert tipinde olup tek boyuttan oluşmaktadır. Kendini sabotaj puanı ölçekte yer alan 3, 5, 6, 10, 13, 20, 22 ve 23 maddeler ters puanlandiktan sonra tüm maddelerin puanları toplanarak kendini sabotaj puanı elde edilebilmektedir. Ölçekten en düşük 25 en yüksek 125 puan alınabilmektedir. Ölçekten alınan puanların artması kişinin kendini sabotaj eğiliminin yüksek olduğunu göstermektedir. Ölçeğin orjinalinin Cronbach alfa katsayısı .79 olarak belirlenmiştir. Ölçeğin Türkçe uyarlamasında faktör yükleri .34 ile .69 , madde toplam korelasyonu puanlar1 ise .30 ile .63 arasında sıralanmaktadır. Tek boyutlu modelin iyi uyum verdiği görülmüştür. KSÖ’nün Cronbach alfa katsayısı .90 olarak bulunmuştur ${ }^{16}$.

\section{Psikolojik İhtiyaç Doyumunda Denge Ölçeği}

Bireylerin psikolojik ihtiyaçlarını doyum ve doyumsuzluk olarak ele alan ölçek Sheldon ve Hilpert (2012) tarafindan geliştirilmiş Kardaş ve Yalçın (2018) Türkçe geçerlik güvenirliğini gerçekleştirmiştir. 18 maddeden oluşan ölçek 5'li likert tipinde bir ölçme aracı olarak kullanılmaktadır. Ölçekten tam puan alınmamakta, alt boyutlar üzerinden puanlama gerçekleştirilmektedir. Ölçek 6 alt boyutlu ve 3 alt boyutlu olmak üzere iki şekilde kullanılabilmektedir. 6 alt boyutlu modeldeki alt boyutlar; ilişkisellik doyum, ilişkisellik doyumsuzluk, yeterlik doyum, yeterlik doyumsuzluk, özerklik doyum, özerklik doyumsuzluktur. 3 alt boyutlu modele göre alt boyutlar; ilişkisellik, yeterlik ve özerklik alt boyutlarıdır. Ölçek puanlamasında 9 madde olumlu olarak puanlanırken, 9 madde de olumsuz olarak puanlanmaktadır. Ölçeğin orjinalinde ilişkisellik, yeterlik ve özerklik alt boyutları için Cronbach alfa katsayıları sırasıyla .78, .79 ve .78 olarak belirlenmiştir ${ }^{17}$. Türkçe uyarlamasında üç boyutlu modelin Cronbach alfa katsayıları ilişkisellik alt boyutu için .70, yeterlik alt boyutu için .71, özerklik alt boyutu için .74 olarak belirlenmiştir ${ }^{18}$. Bu çalışmada üç alt boyutlu model kullanılmıştır.

\section{Öz-Duyarlık Ölçeği}

Neff ${ }^{19}$ tarafindan geliştirilen Öz-duyarlık Ölçeği'ni Türkçeye uyarlama çalışmasını Akın ve ark. ${ }^{10}$ tarafından gerçekleştirilmiştir. Ölçek 5 'li likert tipinde 26 maddeden oluşmaktadır. Ölçeğin öz sevecenlik, Öz yargılama, paylaşımların bilincinde olma, izolasyon, bilinçlilik ve aşırı özdeşleşmeden oluşan altı alt boyutu bulunmaktadır. Alt boyuttan alınan puanların yüksekliği bireyin ilgili alt boyutun değerlendirdiği özelliklere sahip olduğunu göstermektedir. Toplam puanın ise 1-2.5 aras1 puan düşük, 2.5-3.5 arası puan orta ve 3.5-5 arası puan yüksek düzeyde öz-duyarlığı göstermektedir. Ölçeğin orijinal formunda bu ölçeğe ait maddelerin faktör yükleri, öz-sevecenlik için .71-.77, yargılama için .65.80, paylaşımların bilincinde olma için .57-.79, yabancilaşma için .63-.75, bilinçlilik için .62-.80 ve aşır1-özdeşleşme için .65-.78 arasında değişmektedir. Orijinal ölçekte Cronbach alfa katsayıları ise alt boyutlar iç̧in .75 ve .81 aralığında değişmektedir ${ }^{19}$. Türkçe uyarlamasında alt boyutların Cronbach alfa katsayılar1 .72 ile .80 arasinda bulunmuştur ${ }^{20}$.

\section{Uygulama}

Araştırmanın gerçekleştirilebilmesi için Sinop Üniversitesi İnsan Araştırmaları Etik Kurulundan (No:2019/19, 08.04.2019) gerekli onay alındıktan sonra araştırmanın uygulanması için kurum izinleri alınmıştır. Çalışma Helsinki Deklarasyonu ilkelerine uygun olarak gerçekleştirilmiştir. Katılımcılara araştırmanın amacı ile ilgili sözel ve yazılı olarak bilgi verilmiş gönüllü katılım gösterdiklerine dair yazılı aydınlatılmış onamları alınmıştır. Araştırmanın verileri kurum izni ve etik kurul onayı alındıktan sonra toplanmıştır. Hemşirelik öğrencilerine araştırmanın amac1, önemi ve veri toplama araçlarının nasıl doldurulacağı ile ilgili açılamalar yapılmış, sözel ve yazılı aydınlatılmış onamları alındıktan sonra araştırmaya katılmaya gönüllü olan öğrencilerle uygulama gerçekleştirilmiştir. Verilerin toplanması yaklaşık $10 \mathrm{dk}$ sürmüştür. 


\section{İstatistiksel analiz}

Veri analizi SPSS 25 (IBM Corp., Armonk, New York, USA) programında gerçekleştirilmiştir. Verilerin tanımlayıcı istatistiklerinde sayı, yüzde ve ortalama kullanılmıştır. Verilerin parametrik test varsayımlarını karşıladığı için istatistiksel analiz olarak iki ortalama arasındaki farkın anlamllik testi, tek yönlü varyans analizi ve Tukey HSD analizi gerçekleştirilmiştir.

İkili değişkenlerin karşılaştırılmasında yaş, cinsiyet, sınıf gibi değişkenler bağımsız değişken olarak, kendini sabotaj, psikolojik ihtiyaç doyumunda denge ve özduyarlılık toplam puan ve alt boyutları ise bağımlı değişken olarak analiz edilmiştir. Değisskenler arasındaki ilişki pearson korelasyon analizi ile test edilmiştir. Kendini sabotajın, öz-duyarlık ve psikolojik ihtiyaç doyumunda denge üzerindeki etkisini belirlemek için basit doğrusal regresyon analizinden yararlanılmıştır. Verilerin anlamlılığı $\mathrm{p}<0.05$ düzeyinde test edilmiştir.

\section{BULGULAR}

Araştırmaya katılan öğrencilerin yaş ortalaması $21.01 \pm 1.96$ 'dır (18-33 yıl). Kat1limcilarin \%73.4'ü kadın, \%28.8 ‘ birinci sinıf öğrencisi olup \%70.7’si yurtta kaldığını belirtmiştir. Öğrencilerin \%51.5 annesi, \%34.0'ının babası ilkokul mezunudur.

Hemşirelik öğrencilerinin kendini sabotaj toplam puanı ortalamanın üzerinde olduğu belirlenmiştir. ( $\mathrm{X} \pm \mathrm{SS}=80.96 \pm 11.19$, min-max puan aralı̆g 36-118). Psikolojik ihtiyaç doyumunda denge ölçeğinin alt boyutları incelendiğinde ise öğrencilerin en yüksek ilişkisellik puan ortalamasının, en düşük ise özerklik puan ortalamasının olduğu saptanmıştır (ilişkisellik $\mathrm{X} \pm \mathrm{SS}=22.97 \pm 3.78$ ), özerklik $\mathrm{X} \pm \mathrm{SS}=20.85 \pm 3.83$ ). Katılımcıların öz-duyarlık toplam puanı ise orta düzeyde olduğu görülmektedir ( $\mathrm{X} \pm \mathrm{SS}=3.26 \pm 0.61$ ). Öz-duyarlık alt boyutlarından en yüksek bilinçlilik en düşük ise öz yargılama puanının olduğu belirlenmiştir (Tablo 1).

Tablo 1: Hemşirelik öğrencilerinin kendini sabotaj, psikolojik ihtiyaç doyumunda denge ve öz-duyarlık puan ortalamaları

\begin{tabular}{|c|c|c|c|}
\hline & Ortalama & Standart Sapma & Min-Max \\
\hline Kendini Sabotaj Toplam & 80.96 & 11.19 & $36-118$ \\
\hline \multicolumn{4}{|c|}{ Psikolojik İhtiyaç Doyumunda Denge Ölçeği Alt Boyutlar1 } \\
\hline İlișkisellik & 22.97 & 3.78 & $7-30$ \\
\hline Yeterlik & 21.42 & 3.88 & $7-30$ \\
\hline Özerklik & 20.85 & 3.83 & $6-30$ \\
\hline \multicolumn{4}{|c|}{ Öz-duyarlık Ölçeği Toplam Puan ve Alt Boyutları } \\
\hline Öz-duyarlık Toplam & 3.26 & 0.61 & $1.04-4.85$ \\
\hline Özsevecenlik & 3.20 & 0.75 & $1-5$ \\
\hline Öz yargilama & 2.40 & 0.88 & $1-5$ \\
\hline Paylaşımların bilincinde olma & 3.25 & 0.79 & $1-5$ \\
\hline İzolasyon & 2.75 & 0.93 & $1-5$ \\
\hline Bilinçlilik & 3.33 & 0.78 & $1-5$ \\
\hline Aşırı özdeşleşme & 2.81 & 0.93 & $1-5$ \\
\hline
\end{tabular}

Demografik değişkenlerden cinsiyete göre psikolojik ihtiyaçlar denge doyumu ve öz-duyarlık alt boyutlarında anlamlı farklılığa rastlanmıştır. İlişkisellik, aşırı özdeşleşme puanı kadın öğrencilerde, öz yargılama puanı ise erkek öğrencilerde yüksek olduğu belirlenmiştir. Öz-duyarlık alt boyutlarından Öz yargılama puanı erkeklerde öğrencilerde kadın öğrencilerden, aşırı özdeşleşme puanı ise kadın öğrencilerde erkek öğrencilerden daha yüksek olduğu saptanmıştır.
Yaşa göre psikolojik ihtiyaçlar doyumunda denge ölçeği alt boyutlarından özerklik puanı 18-20 yaş aralığında 20-23 yaş aralığından daha yüksek olduğu saptanmıştır.

Sinıfa, kalınan yere, anne ve baba eğitim durumuna göre ise kendini sabotaj, psikolojik ihtiyaç doyumunda denge ve öz-duyarlık toplam puan ve alt boyutlarında herhangi bir farklılı̆̆a rastlanmamıștır (Tablo 2). 
Tablo 2: Demografik değişkenlere göre kendini sabotaj, psikolojik ihtiyaç doyumunda denge ve öz-duyarlık düzeyleri

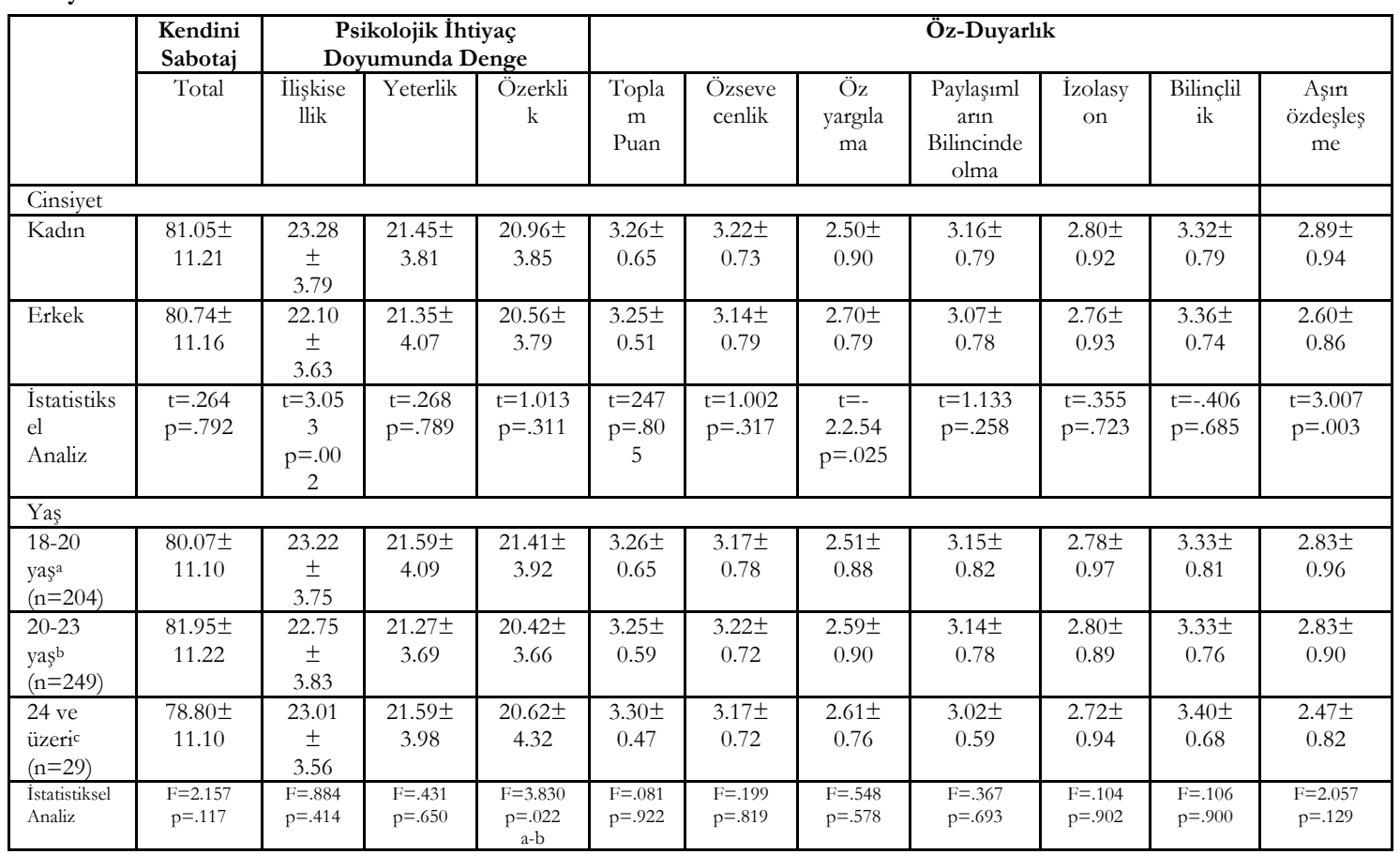

Tablo 3. Kendini sabotaj, öz-duyarlık ve psikolojik ihtiyaç doyumunda denge ölçekleri aralarındaki ilişki

\begin{tabular}{|l|c|c|c|c|c|c|c|c|c|c|c|}
\hline & $\mathbf{1}$ & $\mathbf{2}$ & $\mathbf{3}$ & $\mathbf{4}$ & $\mathbf{5}$ & $\mathbf{6}$ & $\mathbf{7}$ & $\mathbf{8}$ & $\mathbf{9}$ & $\mathbf{1 0}$ & $\mathbf{1 1}$ \\
\hline $\begin{array}{l}\text { 1. Kendini } \\
\text { Sabotaj }\end{array}$ & - & & & & & & & & & & \\
\hline 2. İlişkisellik &,$- 316^{* *}$ & & & & & & & & & & \\
\hline 3. Yeterlik &,$- 423^{* *}$ &, $455^{* *}$ & & & & & & & & & \\
\hline 4. Özerklik &,$- 360^{* *}$ &, $412^{* *}$ &, $488^{* *}$ & & & & & & & & \\
\hline $\begin{array}{l}\text { 5. Öz-duyarlık } \\
\text { Toplam Puan1 }\end{array}$ &,$- 510^{* *}$ &, $376^{* *}$ &, $480^{* *}$ &, $468^{* *}$ & & & & & & & \\
\hline 6. Özsevecenlik &,$- 241^{* *}$ &, $240^{* *}$ &, $353^{* *}$ &, $311^{* *}$ &, $733^{* *}$ & & & & & & \\
\hline 7. Özyargılama &, $470^{* *}$ &,$- 356^{* *}$ &,$- 412^{* *}$ &,$- 416^{* *}$ &,$- 781^{* *}$ &,$- 354^{* *}$ & & & & & \\
\hline $\begin{array}{l}\text { 8. Paylaşımların } \\
\text { Bilincinde olma }\end{array}$ &,$- 109^{*}$ &, $192^{* *}$ &, $214^{* *}$ &, $197^{* *}$ &, $580^{* *}$ &, $620^{* *}$ &,$- 204^{* *}$ & & & & \\
\hline 9. İzolasyon &, $509^{* *}$ &,$- 341^{* *}$ &,$- 384^{* *}$ &,$- 422^{* *}$ &,$-733^{* *}$ &,$- 258^{* *}$ &, $686^{* *}$ &,$- 103^{*}$ & & & \\
\hline \begin{tabular}{l} 
10. Bilinçlilik \\
\hline
\end{tabular} &,$- 316^{* *}$ &, $275^{* *}$ &, $390^{* *}$ &, $333^{* *}$ &, $750^{* *}$ &, $731^{* *}$ &,$- 348^{* *}$ &, $581^{* *}$ & - & & \\
\hline $\begin{array}{l}11 . \text { Asşır1 } \\
\text { Özdeşleşme }\end{array}$ &, $520^{* *}$ &,$- 213^{* *}$ &,$- 320^{* *}$ &,$- 331^{* *}$ &,$- 763^{* *}$ &,$- 320^{* *}$ &, $652^{* *}$ &,$- 182^{* *}$ &, $703^{* *}$ &,$- 403^{* *}$ & - \\
\hline
\end{tabular}

${ }^{* *} \mathrm{p}<0.01 \quad{ }^{*} \mathrm{p}<0.05$

Kendini sabotaj puanı ile psikolojik ihtiyaçlar denge doyumu arasında negatif yönde orta düzeyde bir ilişki belirlenmiştir (ilişkisellik $\mathrm{r}=-.316$; yeterlik $\mathrm{r}=-.423$; özerklik r=-.360). Kendini sabotaj puanı öz-duyarlık toplam puanı, Özsevecenlik, paylaşımların bilinci olma, bilinçlilik alt boyutları ile negatif ilişkili (korelasyon katsayısı aralığ1 -.510-, -.109), izolasyon,
Öz-yargılama ve aşırı özdeşleşme alt boyutları ile ise pozitif ilişkide (korelasyon katsayısı aralı̆̆1 .520, .470) olduğu görülmektedir. Öz-duyarlık toplam puanı ile ilişkisellik, yeterlik ve özerklik puanları aralarında orta düzeyde pozitif bir ilişki belirlenmiştir (korelasyon katsayısı aralığı $.468, .376$ ). Başka bir ifadeyle kendini sabotaj puanı azaldıkça öz-duyarlık ve psikolojik 
ihtiyaç doyumunda denge puanlarının arttığı saptanmıştır (Tablo 3).

Kendi sabotaj puanı azaldıkça öz-duyarlık toplam puanı $(\beta=-0.510, \mathrm{p}<0.001)$ ve psikolojik ihtiyaç doyumunda denge ölçeği alt boyutlarından ilişkisellik $(\beta=-0.316, p<0.001), \operatorname{yeterlik}(\beta=-0.423 p<0.001)$ ve özerklik $(\beta=-0.360, \mathrm{p}<0.001)$ puanı artmaktadır. Kendini sabotaj puanı, öz-duyarlık toplam puanını $\% 26$, ilişkisellik puanın $\% 10$, yeterlilik puanını $\% 18$, özerklik puanını ise \%13 açıkladığı belirlenmiştir (Tablo 4).

Tablo 4. Kendini sabotajın öz-duyarlık ve psikolojik ihtiyaç doyumunda denge üzerine etkisi.

\begin{tabular}{|l|c|c|c|c|c|c|}
\hline Kendini Sabotaj & $\beta$ & SD & B & R2 & F & p \\
\hline $\begin{array}{l}\text { Öz-Duyarlik } \\
\text { Toplam Puanı }\end{array}$ & -.510 & .002 & -.028 & .260 & 169.074 & $<.001$ \\
\hline Ilişkisellik & -.316 & .015 & -.107 & .100 & 53.425 & $<.001$ \\
\hline Yeterlik & & & & .179 & 104.895 & $<.001$ \\
\hline Özerklik & -.423 & .014 & -.147 & .129 & 71.392 & $<.001$ \\
\hline
\end{tabular}

\section{TARTIŞMA}

Araştırmanın bulguları incelendiğinde hemşirelik ögrencilerinde kendini sabotaj puanının ortalamanın üzerinde, öz-duyarlılığın orta düzeyde ve ilişkisellik puanının ise en yüksek olduğu belirlenmiştir. Literatür incelemesinde de benzer biçimde hemşirelik öğrencilerinde öz-duyarlığın orta düzeyde olduğu saptanmıştır ${ }^{9,21,22}$. Bakımda şefkati ön plana alan özduyarlık geliştirilebilen bir özellik olup mesleki açıdan ilişkilerin gelişimi ve kaliteli bakımın sağlanmasında önemli bir role sahiptir. Bu nedenle hemşirelik öğrencilerinde öz-duyarlığın yükselmesinde mesleğe adım atmadan akademik yaşam boyunca gelişimine yönelik üzerinde çalışılması gerekmektedir. Bir diğer değişken olan psikolojik ihtiyaçlardan ilişkisellik puanının hemşirelik öğrencilerinde yüksek, özerklik puanının ise düşük olduğu belirlenmiştir. İlişkili olma ihtiyacı başkalarıyla etkileşim içinde olma, onlarla ilgilenmeyi istemeyi içermektedir ${ }^{23}$. Adölesan dönemde akranlar ve başkalarıyla bir arada bulunma, onların onayını alma, gruplarına dahil olma, ilişkilerin devamlılığ1 ve sürdürülmesi dönemin gereksinimleri açısından da önemli bir yeri bulunmaktadır. Orkibi, Ronen $^{24}$ adölesanlarda gerçekleştirdiği çalışma da ilişkisellik puan ortalamasının en yüksek olduğu saptanmıştır. Kültüre göre ilişkisel ve özerk benlik kurguları değişebilmekte olup ülkemiz gibi toplulukçu kültürlerde ilişkisel benlik kurgusu daha ön plandadır ${ }^{18}$. Bu durumda aslında öğrencilerin kişilerarası ilişkileri önemsediklerini göstermektedir. Diğer yandan özerklik puanının düşük olması ise karar alma süreçlerini zamanla olumsuz etkileyebilir. $\mathrm{Bu}$ nedenle öğrencilerin istek ve tercihlerine uygun bir biçimde özerkliklerini kazanmalarına yönelik eleştirel düşünme, problem çözme gibi becerilerinin gelişimine yönelik çeşitli fırsatlar sağlanabilir.

Demografik değişkenlerden cinsiyet, yaş gibi değişkenlere göre psikolojik ihtiyaçlar ve öz-duyarlık puanlarına göre anlamlı farklılıklar belirlenmiştir. Cinsiyete göre öz-duyarlık puanı incelendiğinde öz yargılama puanı erkeklerde kadınlardan, aşırı özdeşleşme puanı ise kadınlarda erkeklerden daha yüksek olduğu saptanmıştır. Bu bulgu kadınların ve erkeklerin baş etme biçimleri arasındaki farkı yansıttığ1 söylenebilir. Kadınların olayları duygusal açıdan, erkeklerin ise sorunlarının çözümünde içsel bir yaklaşım sergileyerek yargılama sürecinden geçirerek bireysel olarak ele almaya yatkın olduğu söylenebilir. Murn ve Steele ${ }^{25}$ çalışmasında aşı11 özdeşleşme puanının kadınlarda erkeklerden daha yüksek olduğu bulunmuştur Grififth ${ }^{26}$ kolej öğrencilerinde gerçekleştirdiği çalışmasında öz yargılama ve aşırı özdeşleşmenin kadınlarda erkeklerden daha yüksek olduğunu belirlemiştir. $\mathrm{Neff}^{27}$ öz yargılamayı bireyin başarısızlıklara yönelik duygusal açıdan tepkisini içerdiğini belirtmektedir.

Cinsiyete göre psikolojik ihtiyaç doyumunda ilişkisellik puanının kadın ögrrencilerde erkek öğrencilere göre daha yüksek olduğu belirlenmiştir. Benzer biçimde gerçekleştirilen çalışmalarda da bu bulguyu desteklemektedir ${ }^{28,29}$. Kadınların ilişkileri, etkileşim içinde olabilmeyi bu gereksiniminin ise daha ön planda olduğu ortaya konulmaktadır. Bir diğer yandan Sapmaz ve ark $^{30}$ gerçekleştirdiği psikolojik ihtiyaçların mutluluktaki rolünün incelendiği çalışmada cinsiyete göre herhangi bir farklilığa rastlanmamıştır. Kendini sabotaj puanında ise cinsiyete göre herhangi bir farklılığa rastlanmamıştır. 
Her iki cinsiyette kendini engelleme stratejilerini kullanabildiğini gösteren pek çok çalışmaya bulunmaktadır ${ }^{31-35}$. Özellikle üniversite yaşamının ergenlik dönemini de içine aldığı düşünüldüğünde bu gelişimsel dönemden de kendini sabote etme davranışlarına yönlenme görülebilmektedir ${ }^{33}$. Bir diğer taraftan bu çalışmanın tersine Anlı ve ark. ${ }^{1}$ gerçekleştirdiği çalışmada ise erkek öğrencilerin kendini sabotaj puanlarının kadın öğrencilerden daha yüksek olduğu belirlenmiştir.

Yaşa göre 18-20 yaş aralığında 20-23 yaş aralığına göre özerklik ihtiyacının daha yüksek olduğu belirlenmiştir. Üniversite yıllarının ilk başlangıcı aileden ayrilıkların görüldüğü yeni bir ortam, yeni bireylerle bir arada yaşandığ bağımsızlığın üst düzeyde olduğu dönemdir. Bu dönemde rollerinde farklılaşması seçimleri etkilemekte ve özerklik duygularını da ön plana getirebilmektedir. Özerklik ihtiyacı bireyin kendi eylemleri ile ilgili dışsal ve içsel olarak karar alma sürecine katılmasıyla ilgilidir.

Çalışmada kendini sabotaj puanı arttıkça öz-duyarlık toplam puanının ve psikolojik ihtiyaçların azaldığı belirlenmiştir. Ayrıca kendini sabotaj özduyarlılığ1 \%26 açıkladığı saptanmıştır. Literatür incelemesinde de çalışma ile benzer biçimde kendini sabotaj özduyarlığın negatif yönde açıkladığı yordadığı saptanmıştır ${ }^{36-38}$. Öz-duyarlı bireyler değerlendirmeler karşısında tehdit altında hissetme düzeyleri daha az olduğundan olumlu ve olumsuz değerlendirmeleri kabul etmektedir ${ }^{38}$. Ancak kendini sabote eden bireyler olumsuz değerlendirmeyi benliğine yönelik bir tehdit olarak algılayabildiğinden bu durumu başkalarına yükleyebilmektedir. Başkalarını suçlama, olayları gerçek algılamayı bozabilir ve hemşirelerin mesleki performans ve bakım kalitesini olumsuz etkileyebilmektedir.

Katılımcıların tümü iki üniversitede eğitim gören hemşirelik öğrencileri olduğu için araştırmanın kapsamındaki sınırliliktan söz edilebilir. Bu nedenle araştırma bulguları tüm hemşirelik bölümlerine genellenememektedir.

Sonuç olarak bu çalışmada hemşirelik öğrencilerinin kendini sabotaj, öz-duyarlık ve psikolojik ihtiyaç doyumunda denge aralarındaki ilişki incelenmiştir. Öğrencilerin orta düzeyde öz-duyarlığa sahip olduğu bilinçlilik puanın en yüksek, öz yargılama puanının ise en düşük, psikolojik ihtiyaçların doyumunda ise ilişkisellik puanının en yüksek olduğu belirlenmiştir. Kendini sabotaj puanı arttıkça öz-duyarlık ve psikolojik ihtiyaçların ise azaldığı saptanmıștır.
Gerçekleştirilen regresyon analizinde ise kendini sabotajın öz-duyarlığ1 \%26 açıkladığ1 bulunmuştur. Elde edilen sonuçlar doğrultusunda bireylerin kendini engelleme davranışlarının önlenmesinde özduyarlı̆̆ın ve psikolojik ihtiyaçların önemli yeri olduğu ortaya konulmaktadır. Bu doğrultuda ilerde mesleğe adım atacak olan hemşirelik öğrencilerinin benliğinin güçlendirilmesi, psikolojik gereksinimlerinin dikkate alınması iyi oluşluluğunu artırıcı davranıșlara yöneltilmesi başarısızlıklarını dışsallaştırmalarını önleyecek, kendine ve diğerlerine yönelik daha duyarlı, esnek davranışlar sergilemesine katk1 sağlayabilecektir. Hemşirelik öğrencilerinin mesleki yaşamlarında karar alma süreçlerine yardımcı olacağ1 için yeterlik ve özerkliğin gelişimine yönelik çeşitli programlar oluşturulması önerilebilir. Kendini sabotaj davranışının önlenmesine yönelik sonraki çalışmalarda müdahale çalışmalarına yer verilmesi öğrencilerin mesleki yaşamı için önemli adımlar olacağ1 düşünülmektedir. Daha büyük örneklemlerde de benzer çalışmalar ve izlem çalışmaları da gerçekleştirilebilir.

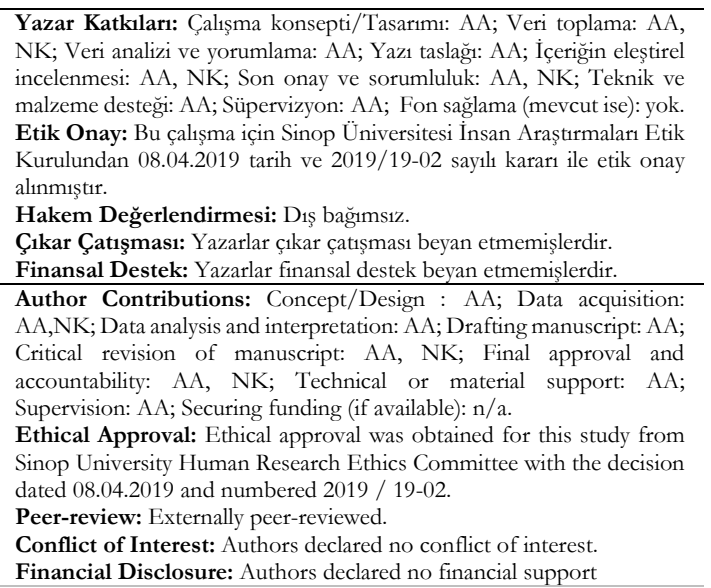

\section{KAYNAKLAR}

1. Anlı G, Akın A, Şar AH, Eker H. Kendini sabotaj ile psikolojik iyi olma arasındaki ilişkinin çeşitli değişkenler açısından incelenmesi. Elektronik Sosyal Bilimler Dergisi. 2015;14:160-172.

2. Berglas S, Jones EE. Drug choice as a selfhandicapping strategy in response to non-contingent success. J Pers Soc Psychol.. 1978;36:405-17.

3. Török L, Szabo ZP The theory of self-handicapping: forms, influencing factors and measurement. Československá psychologie. .2018;173-188.

4. McCrea SM, Hirt ER. The role of ability judgments in self-handicapping. Pers Soc Psychol Bull.. 2001;27:378-1389. 
5. Yavuzer Y. Investigating the relationship between self-handicapping tendencies, self-esteem and cognitive distortions. Educ Sci Theory Pract. 2015;15:879-90.

6. Chen Z, Sun K, Wang K. Self-esteem, achievement goals, and self-handicapping in college physical education. Psychol Rep. 2018;121:690-704.

7. Üzar Özçetin YS, Hiçdurmaz D. Kendini sabote etme ve ruh sağllğı üzerine etkisi. Psikiyatride Güncel Yaklaşımlar-Current Approaches in Psychiatry 2016;8:145-154.

8. Sakız H, Sarıçam H. Self-compassion and forgiveness: The protective approach against rejection sensitivity, International Journal of Human Behavioral Science. 2015;1:10-21.

9. Hiçdurmaz D, Aydın A. The relationship between nursing students' self compassion and multidimensional perfectionism levels and the factors that influence them. Journal of Psychiatric Nursing. 2017;8:86-94

10. Bulduk S, Ardıç E. Hemşirelik öğrencilerinde öz duyarlılığın incelenmesi. G.O.P. Taksim E.A.H. JAREN. 2015;1:60-65.

11. Nazik E, Arslan S. Hemşirelik öğrencilerinin empatik becerileri ile öz duyarlıkları arasındaki ilisskinin incelenmesi. Anadolu Hemşirelik ve Sağlık Bilimleri Dergisi. 2011;14:69-75.

12. Gunnel KE, Mosewich AD, McEwen CE, Eklund RC, Crocker P. Don't be so hard on yourself! Changes in self-compassion during the first year of university are associated with changes in well-being. Pers Individ Diff. 2017;107:43-48.

13. Barutçu Yıldırım F, Demir A. Self-handicapping among university students: the role of procrastination, test anxiety, self-esteem, and self-compassion. Psychol Rep. 2019;. doi:10.1177/0033294118825099.

14. Kaya H, Altun ŞÖ. Hemşirelerin temel psikolojik ihtiyaçları ve etkileyen faktörler. Sağlık Bilimleri ve Meslekleri Dergisi. 2018;5:295-305.

15. Jones EE, Rhodewalt F. The-self handicapping scale. (Available from Frederick Rhodewalt, Dept. of Psychology, University of Utah, Salt Lake City, UT 84112). 1982.

16. Akın A. Self-handicapping scale: A study of validity and reliability. Educ Sci. 2012;37:177-188.

17. Sheldon KM, Hilpert JC. The balanced measure of psychological needs (BMPN) scale: An alternative domain general measure of need satisfaction. Motiv Emo. 2012;36:439-51

18. Kardaş F, Yalçın N. An adaptation study of the Balanced Measure of Psychological Needs (BMPN) Scale to Turkish culture. Çukurova Üniversitesi Eğitim Fakültesi Dergisi. 2018;47:357-83.

19. Neff KD. The development and validation of a scale to measure self-compassion. Self Identity. 2003;2:22350 .
20. Akın Ü, Akın A, Abacı, R. Öz-duyarlık ölçeği: Geçerlik ve güvenirlik çalışması. Hacettepe Üniversitesi Eğitim Fakültesi Dergisi. 2007;33:1-10.

21. Eraydın Ş, Karagözoğlu Ş. Investigation of selfcompassion, self-confidence and submissive behaviors of nursing students studying in different curriculums. Nurse Educ Today. 2017;54:44-50.

22. Şenyuva E, Kaya H, Ișik B, Bodur G. Relationship between self-compassion and emotional intelligence in nursing students. Int J Nurs Pract. 2014;20:588-96.

23. Ryan RM. Psychological needs and the facilitation of integrative processes. J Pers. 1995; 63: 397-427.

24. Orkibi H, Ronen T. Basic psychological needs satisfaction mediates the association between selfcontrol skills and subjective well-being. Front Psychol. 2017;8:936

25. Murn LT, Steele MR. What matters most? Age and gender differences in self-compassion and body attitudes among college students, Counsel Psychol Q. 2020;33:541-560.

26. Grififth ER. Spirituality and self-compassion among college students. 94th Annual Meeting Abstracts. 2019; 91(1). http://pwvas.org/index.php/pwvas/article/view/46 8.

27. Neff KD. The self-compassion scale is a valid and theoretically coherent measure of self-compassion. Mindfulness. 2015;7:264-74.

28. Cihangir Çankaya Z. Öğretmen adaylarında temel psikolojik ihtiyaçların doyumu ve iyi olma. Türk Eğitim Bilimleri Dergisi. 2009;7:691-711.

29. Harvey VS, Retter K. Variation of gender differences between children and adolsecents on the four basic psychological needs. International Journal of Reality Therapy. 2002;21:33-6.

30. Sapmaz F, Doğan T, Sapmaz S, Temizel S, Tel F. Examining predictive role of psychological need satisfaction on happiness in terms of selfdetermination theory. Procedia Soc Behav Sci. 2012;55:861-8.

31. Topal S, Yalnızoğlu Çaka S, Çınar N. Determination of the relationship between self-handicapping and burnout of nursing students. Çukurova Üniversitesi Eğitim Fakültesi Dergisi.2018;47:337-56.

32. Kalyon A, Dadandi I, Yazıc1, H. The relationships between self-handicapping tendency and narcissistic personality traits, anxiety sensitivity, social support, academic achievement. Dusunen Adam. 2016;29:23746.

33. Zarshenas L, Jahromi, LA, Jahromi, MF. et al. Selfhandicapping among nursing students: an interventional study. BMC Med Educ. 2019; 19, 26.

34. Büyükgöze $H$, Gün F. Araştırma görevlilerinin kendini sabotaj eğilimlerinin incelenmesi. Hitit Üniversitesi Sosyal Bilimler Enstitüsü Dergisi. 2015;8:690-704. 
35. Kamuk YU, Şensoy E. Dalga sörfü hakemlerinin kendini sabotaj düzeyleri. Turkish Studies Social Sciences. 2019;14:683-95.

36. Akin U, Akın A. The predictive role of selfcompassion on self-handicapping in Turkish university students. Ceskoslovenska Psychologie. 2015;59:33-43.
37. Petersen L. Self-compassion and self-protection strategies: The impact of selfcompassion on the use of self-handicapping and sandbagging. Pers Individ Diff 2014;56:133-8.

38. Barutçu Yıldırım F, Demir A. Kendini engellemenin yordayıcıları olarak öz sayg1, öz anlayış ve akademik özyeterlilik. Ege Eğitim Dergisi. 2017;2:676-701. 